\title{
Effect of air heat treatment time on physical, chemical and DNA quality properties of strawberry fruit (cv. Candonga)
}

\author{
Mauro Musto, Raffaele Lopardo, Francesco Cellini, Pasquale Domenico Grieco \\ Metapontum Agrobios, Metaponto (MT), Italy
}

\begin{abstract}
Changes in quality properties of air heat-treated $\left(45^{\circ} \mathrm{C}\right.$ for 0,2 and $4 \mathrm{~h})$ strawberries were investigated. As treatment time increased, most of physical, chemical and DNA quality properties decreased significantly. After $4 \mathrm{~h}$, however, fruits showed the highest $L^{*}$ value, Hue angle, $\mathrm{pH}$, soluble solids content (SSC) and total phenolic accumulation. The results of multiplex PCR assays showed two amplified fragments for all samples extracted from achenes. In thalamus, conversely, the number of amplified fragments decreased with time, indicating great degradation of DNA in this tissue.
\end{abstract}

\section{Introduction}

Consumption of fruits and vegetables provides reduction of heart diseases, free radicals and hypertension, improvement on weight control and even reduction of the risk of some cancers (Halliwell, 1994; Ho and Shahidi, 2005). These health-promoting properties are associated with antioxidant compounds, such as anthocyanins, vitamin C, and phenolic acids, which offer protection against harmful free radicals. In

Correspondence: Dr. Mauro Musto, Metapontum Agrobios S.r.l., s.s. 106 Jonica Km 448.2, 75010 Metaponto (MT), Italy.

Tel. +39.0835.740232 - Fax: +39.0835.740204. E-mail: mmusto@agrobios.it

Key words: genomic DNA, heat treatment, multiplex PCR, quality properties, strawberries.

Acknowledgements: the work was supported by a grant for young researchers provided by Regione Basilicata within the program GEL (Giovani Eccellenze Lucane - POR 2000/2006, Measure III.1.D.4). Strawberry fruits were kindly provided by Planitalia S.r.l. (Policoro, Matera, Italy). The authors would like to thank G. Morano and R. Novario for technical assistance.

Received for publication: 10 September 2010.

Accepted for publication: 3 February 2011.

(C) Copyright M. Musto et al., 2011

Licensee PAGEPress, Italy

Italian Journal of Agronomy 2011; 6:e11

doi:10.4081/ija.2011.e11

This article is distributed under the terms of the Creative Commons Attribution Noncommercial License (by-nc 3.0) which permits any noncommercial use, distribution, and reproduction in any medium, provided the original author(s) and source are credited. addition to the usual nutrients, such as vitamins and minerals, strawberries are a good dietary source of these bioactive compounds (Heinonen et al., 1998; Rice-Evans and Miller, 1996) and, among the fruits, they have one of the highest antioxidant activity (Cordenunsi $e t$ al., 2002; Wang et al., 1996). Depending on their content of antioxidant molecules, these fruits have antioxidant, anticancer, anti-inflammatory and anti-neurodegenerative biological properties (Hannum, 2004), so that they can be considered healthy-foods. Strawberries, however, are highly perishable after harvest and susceptible to mechanical injury, physiological deterioration, water loss, and microbial decay, thus, without appropriate treatment and storage conditions, their quality rapidly declines. During the past few years, there has been increasing interest in the use of physical treatments to extend the shelf life of fruit and vegetable products. As an eco-friendly alternative to chemically decontamination, heat treatments can control insect pests, prevent pathogen infection, increase resistance to chilling injury, delay fruit ripening and extend postharvest shelf life (Civello et al., 1997; Ketsa et al., 1998; Wang, 1998). Couey and Follstad (1966) claimed that heat treatments had a beneficial effect on strawberry fruit. Nevertheless, in recent studies contradictory results have been reported. For instance, reports on Chandler (Yoshikawa et al., 1992) and Pájaro (Lara et al., 2006) strawberries have shown that firmness was similar in air-heated and untreated fruit. Selva strawberries treated with hot air showed delayed softening rates (Civello et al., 1997; Vicente et al., 2002), although no difference was observed in recent studies (Vicente et al., 2003, 2005). In addition, hot water dips has been reported to affect strawberry firmness positively in Tudla (García et al., 1995) and negatively in Pájaro (Lara et al., 2006). Observed changes are related to cultivar differences and heating procedures, as well as time of exposure (Lurie, 1998). Besides, the benefit of using heat treatments can result in a loss of those distinctive morphological features that are necessary for product identification. There is, therefore, a need to verify the applicability of those techniques that allow authenticating food products, even after intensive treatments. DNAbased analyses of food products have been demonstrated to be an efficient mean for compositional analysis including plant speciation (Knight, 1998), meat, milk and fish adulteration (Meyer et al., 1995; Piknova et al., 2002; Sanjuan and Comesana, 2002), microbial contamination (Agarwal et al., 2002), and detection of plant ingredients derived from genetically modified plants (Hubner et al., 2001). The prerequisite for DNA-based analyses is the availability of high quality genomic DNA. Several studies demonstrated that there is a significant DNA degradation during food processing (Peano et al., 2004; Tilley, 2004; Arslan et al., 2006), so that DNA quality parameters (i.e. yield, purity, degradation, etc.), in combination with other physical and chemical parameters, could provide valuable information for monitoring postharvest treatments. Considering that reported effects of heat treatments on strawberry quality have been diverse for different cultivars, and that there is a lack of results on comparing different times of exposure, this preliminary work was undertaken to study the effect of hot air treatment time on quality properties of Candonga strawberry 
fruits, for which no results are yet available. This cultivar has a 50\% share of the market in Southern Italy; in Basilicata, it already has a share of $85 \%$ (Watson, 2010). A further aim was to evaluate whether such treatments could affect the ability to extract, amplify and identify DNA from heat-treated fruits.

\section{Materials and Methods}

\section{Sampling and heat treatments}

Strawberries (Fragaria $x$ ananassa cv. Candonga) were harvested in the summer of 2007 (June 27), early in the morning (05:00 h $\div 06: 00 \mathrm{~h}$; $17.79^{\circ} \mathrm{C}$; RH: $98.90 \%$; total solar radiation: $130.3 \mathrm{Kj} / \mathrm{m}^{2}$ ), and transferred to the laboratory within $3 \mathrm{~h}$. Fruits for processing were selected according to their appearance (i.e. uniform size and $75 \%$ red color), washed in distilled water, dried with a paper towel to remove undesirable materials and the peduncles removed. Then they were classified into three homogeneous groups and held in an air oven at $45^{\circ} \mathrm{C}$ for 0,2 and $4 \mathrm{~h}$. After the heat treatments, each group was immediately analyzed.

\section{Physical analysis}

The fruits of each group were individually weighed with an electronic digital balance (Model PM 400, Mettler, Greifensee, Switzerland). External color was measured on three points of each fruit using a reflectance colorimeter (Model CR 200, Minolta, Ramsey, NJ, USA). Color was recorded using the CIE- $L^{*}, a^{*}, b^{*}$ uniform color space, in which the $L^{*}$ scale ranges from no reflection $\left(L^{*}=0\right.$, black) to perfect diffuse reflection $\left(L^{*}=100\right.$, white), the $a^{*}$ scale ranges from negative values for green to positive values for red, and the $b^{*}$ scale ranges from negative values for blue to positive values for yellow. Numerical values of $a^{*}$ and $b^{*}$ were used to calculate Chroma $\left(\left[a^{* 2}+b^{* 2}\right]^{1 / 2}\right)$, which indicates the intensity or color saturation, and Hue angle (arctangent $\left[b^{*} / a^{*}\right]$ ), where $0^{\circ}=$ red-purple, $90^{\circ}=$ yellow, $180^{\circ}=$ bluishgreen and $270^{\circ}=$ blue (McGuire, 1992). Fruit firmness was measured using a penetrometer (Model FT 011, TR Scientific Instruments, Forlì, Italy) at 1 or 2 points on the shoulder of strawberry by applying a plunger of $6 \mathrm{~mm}$ in diameter.

\section{Chemical analysis}

The thalamus tissue of each fruit was separated manually from achenes and homogenized in a refrigerated blender at high speed for 2 min. The resultant homogenate was used for chemical measurements. A precise amount $(1 \mathrm{~g})$ of homogenate was centrifuged at $1,500 \mathrm{x} g$ for $10 \mathrm{~min}$, the resulting supernatant filtered and used for determination of soluble solids content (SSC). SSC was determined using a digital refractometer (Model PR, Atago, Tokyo, Japan) and results were expressed in percentage (\%). One gram of homogenised tissue was poured into $9 \mathrm{~mL}$ of distilled water and $\mathrm{pH}$ of the filtered solution was measured using a standard $\mathrm{pH}$ meter (Model 744, Metrohm AG, Herisau, Switzerland), previously standardized to $\mathrm{pH} 4$ and 7. Total anthocyanins and total soluble phenolics (TSP) were extracted overnight at $4^{\circ} \mathrm{C}$ from $1 \mathrm{~g}$ of homogenate with $9 \mathrm{~mL}$ of methanol containing $0.1 \%(\mathrm{v} / \mathrm{v})$ of $\mathrm{HCl}$. After centrifugation at $1,500 \mathrm{x} g$ for $10 \mathrm{~min}$, the supernatant was filtered and its absorbance at $510 \mathrm{~nm}$ was measured. The amount of anthocyanins was calculated using the extinction coefficient $\left(\varepsilon\right.$ ) equal to $3.6 \times 10^{-6} 1 \mathrm{~mol}^{-1} \mathrm{~m}^{-1}$ (Woodward, 1972). Total anthocyanins content was expressed as mg of pelargonidin-3-glucoside (PGN) per $\mathrm{g}$ of tissue. For measuring TSP content, $1 \mathrm{~mL}$ of the same supernatant was added to $5 \mathrm{~mL}$ of $10 \%(\mathrm{v} / \mathrm{v})$ of Folin-Ciocalteau reagent (Singleton and Rossi, 1965). After $3 \mathrm{~min}$ at $\sim 24^{\circ} \mathrm{C}$ (ambient), $4 \mathrm{~mL}$ of saturated solution of $7.5 \%(\mathrm{w} / \mathrm{v})$ of $\mathrm{Na}_{2} \mathrm{CO}_{3}$ were added, and the reac- tion mixture was incubated for $2 \mathrm{~h}$ at the same temperature. The absorbance of the resulting blue color was measured at $760 \mathrm{~nm}$ using a UV-Vis Spectrophotometer (Model Cary 50, Varian Inc., Walnut Creek, CA, USA). Quantification was done on the basis of a standard curve of gallic acid and results were expressed as mg gallic acid equivalents (GAE) per $\mathrm{g}$ of tissue. Total ascorbic acid (TAA) was measured by classical titration method using 2,6-dichlorophenol indophenol solution in $\mathrm{mg} / \mathrm{g}$ tissue (Charalambous, 1984; Miller, 1998).

\section{DNA analysis}

DNA was extracted separately from the achenes and the thalamus of each fruit. Both tissues were ground in liquid nitrogen by pestle and mortar. The resultant powder $(\sim 1 \mathrm{~g})$ was mixed with $5 \mathrm{~mL}$ of washing buffer [100 mM Sodium Acetate Buffer ( $\mathrm{pH} 5.0$ ), $20 \mathrm{mM}$ EDTA (pH 5.0), 0.2 M Sorbitol, 2\% (w/v) PVP (MW 360.000), 2\% (v/v) $\beta$-mercaptoethanol]. After centrifugation $(3,000 \times g$ for $10 \mathrm{~min}$ at $4^{\circ} \mathrm{C}$ ), the supernatant was discarded, the pellet suspended in $2 \mathrm{~mL}$ of extraction buffer (200 mM Tris-HCl [pH 7.5], $1.4 \mathrm{M} \mathrm{NaCl}, 20 \mathrm{mM}$ EDTA, $2 \%(\mathrm{w} / \mathrm{v})$ CTAB, $2 \%(\mathrm{v} / \mathrm{v}) \beta$-mercaptoethanol) and incubated at $65^{\circ} \mathrm{C}$ for $30 \mathrm{~min}$. An equal volume of chloroform:ottanol (24:1 v:v) was added, the sample was vigorously vortexed and then centrifuged $\left(4,000 \times \mathrm{g}\right.$ for $10 \mathrm{~min}$ at $\left.4^{\circ} \mathrm{C}\right)$. The upper phase was transferred into a new tube containing an equal volume of isopropanol and incubated at $0^{\circ} \mathrm{C}$ for $5 \mathrm{~min}$. After centrifugation $\left(4,000 \mathrm{x} g\right.$ for $10 \mathrm{~min}$ at $\left.4^{\circ} \mathrm{C}\right)$, the supernatant was discarded, the pellet suspended in $500 \mu \mathrm{L}$ of ultrapure distilled water and treated with RNAase A $(10 \mu \mathrm{g} / \mu \mathrm{L})$ at $37^{\circ} \mathrm{C}$ for $30 \mathrm{~min}$. RNase reaction was terminated by adding 1 volume of phenol:chloroform (1:1 v:v) first and 1 volume of chloroform:isoamyl alcohol (24:1 v:v) then. DNA was precipitated by adding 1 volume of isopropanol and 0.2 volume of ammonium acetate $(5 \mathrm{M})$. After $1 \mathrm{~h}$ at $20^{\circ} \mathrm{C}$, DNA was pelleted by centrifugation $(16,000 \times \mathrm{g}$ for $10 \mathrm{~min}$ at $4^{\circ} \mathrm{C}$ ), rinsed twice with $75 \%(\mathrm{v} / \mathrm{v})$ ethanol, air-dried and dissolved into $100 \mu \mathrm{L}$ ultrapure distilled water. The integrity of the isolated DNA was checked on a $1 \%(\mathrm{w} / \mathrm{v})$ agarose gel under ultraviolet light, after staining with ethidium bromide $(0.5-1 \mu \mathrm{g} / \mathrm{mL})$. The DNA yield (expressed as $\mu$ g per gram of tissue) was measured with an UV/Vis spectrophotometer (Model ND-1000, NanoDrop, Wilmington, Delaware, USA) and the $\mathrm{A}_{260} / \mathrm{A}_{280}$ and $\mathrm{A}_{260} / \mathrm{A}_{230}$ absorption ratios were verified as quality indexes. A multiplex PCR was carried out to evaluate DNAs for the amplification of two loci simultaneously in the same reaction. Only DNAs detectable on agarose gel under UV was used for PCR amplification. The integrity of DNAs was also evaluated by amplifying fragments of different size. We choose to amplify of a fragment of $480 \mathrm{bp}$ of the Fragaria $x$ ananassa tRNA-Leu (trnL) and tRNA-Phe (trnF) genes (GenBank ${ }^{\circledR}$ Accession \# AF163538) using a set of forward (5'GGTTCAAGTCCCTCTATCCC-3') and reverse primers (5'ATTTGAACTGGTGACACGAG-3'). To amplify the 209 bp fragment of the Fragaria $x$ ananassa cinnamyl alcohol dehydrogenase (cad) gene (GenBank ${ }^{\circledR}$ Accession \# AF320110) were used 5' primer, 5'-GAGGAGGAAGCTCTTAAACACC-3', and 3' primer, 5'-GCAGAAACTGTGTCAATGATCC-3'. Multiplex PCR reactions were performed using a PTC$200^{\mathrm{TM}}$ Peltier Thermal Cycler (MJ Research and Biozym, Hessisch Oldendorf, Germany) in a final volume of $50 \mu \mathrm{L}$ containing $0.1 \mu \mathrm{g}$ genomic DNA template, $20 \mathrm{mM}$ Optimized DyNAzyme ${ }^{\mathrm{TM}}$ Buffer, 0.2 $\mathrm{mM}$ dNTPs, $0.4 \mathrm{mM}$ each primer of four primers and 2.5 units of DyNAzyme $^{\mathrm{TM}}$ II DNA Polymerase (Finnzymes OY, Riihitontuntie, Espoo, Finland). PCR program consisted of 1 cycle of $5 \mathrm{~min}$ at $94^{\circ} \mathrm{C}$; 40 cycles of $30 \mathrm{sec}$ at $94^{\circ} \mathrm{C}, 30 \mathrm{sec}$. at $59^{\circ} \mathrm{C}$, and $1 \mathrm{~min}$ at $72^{\circ} \mathrm{C}$; a final extension of $5 \mathrm{~min}$ at $72^{\circ} \mathrm{C}$ and ultimately kept at $4^{\circ} \mathrm{C}$. The amplification products were resolved by electrophoresis on a $1.5 \%(\mathrm{w} / \mathrm{v})$ agarose gel with ethidium bromide $(0.5-1 \mu \mathrm{g} / \mathrm{mL})$ and visualized under UV. Bands of appropriate size were identified by comparison with a 100 bp marker (Invitrogen, Carlsbad, CA, USA). 


\section{Statistical analysis}

All the variables were tested for normal distribution using the Shapiro-Wilk test (Shapiro and Wilk, 1965). One-way analysis of variance (ANOVA) was used to determine significant differences among samples due to heat treatment time. Means of the triplicate experimental results were ranked according to Tukey's HSD (honestly significant difference) multiple comparison test for responses that showed significance difference. Statistical analyses were performed using Statistica version 7 (StatSoft Inc., Tulsa, OK, USA) software. The presence and absence of bands, visualized under UV on agarose gels used to check DNA quality and multiplex PCR products, was scored (1, 0, respectively) and data were expressed as positive cases of DNA band presence on total cases.

\section{Results and discussion}

\section{Physical analysis}

Results concerning the effect of heat treatment time on physical quality properties of strawberries are shown in Table 1. Strawberry weight decreased during treatment time. Fruits heated at $45^{\circ} \mathrm{C}$ for $4 \mathrm{~h}$ had a lower weight, respectively, than those heated for 2 and $0 \mathrm{~h}$. These differences could be due primarily to different water loss among groups during treatments. Previous studies found that the application of heat treatment $\left(45^{\circ} \mathrm{C}, 3 \mathrm{~h}\right)$ in strawberries cv. Selva caused a weight loss close to $2-3 \%$ (Vicente et al., 2002; 2003). Heat treatments had a negative effect on fruit firmness: when heated for $4 \mathrm{~h}$, strawberries were softer than those treated for 2 and $0 \mathrm{~h}$, respectively. Civello et al. (1997) and Vicente et al. (2002) reported that after the $3 \mathrm{~h}$ of hot air treatments $\left(42,45\right.$ or $\left.48^{\circ} \mathrm{C}\right)$, strawberries were slightly firmer than controls, although no difference was found in other studies (Vicente et al., 2003; 2005) and cultivars (Chandler, Yoshikawa et al., 1992; Pájaro, Lara et $a l ., 2006)$. Based on the results of the current research, heat treatments do not seem to affect positively fruit firmness in strawberries cv. Candonga and changes in softening can be physically explained by the considerable loss of water experienced by strawberries during treatments. The $L^{*}$ value of the strawberries decreased from 0 to $2 \mathrm{~h}$, but the difference was not significant. Vicente et al. $(2002,2003)$ reported a significant loss of lightness treating strawberries at $45^{\circ} \mathrm{C}$ only after 3 $\mathrm{h}$, thus confirming our result. In contrast, $4 \mathrm{~h}$ heat-treated strawberries exhibited a higher $L^{*}$ value compared to strawberries from the other two treatment time, meaning that the fruit developed a lighter external color after $4 \mathrm{~h}$ at $45^{\circ} \mathrm{C}$. The external red color of the strawberry fruit $\left(b^{*}\right.$ value), as well as the color saturation (Chroma value), decreased during treatments, with fruits heated for $4 \mathrm{~h}$ showing lower values compared to the samples of other groups. These results indicated that the fruit surface became lower in pigment intensity (i.e. anthocyanins) during treatments. Yellowness ( $b^{*}$ value) was similar in strawberries heated for 0 and $2 \mathrm{~h}$, but decreased significantly after $4 \mathrm{~h}$. Fruits developed a less orange-red color after $2 \mathrm{~h}$ (Hue angle decreased), confirming previous results (Vicente et al., 2002, 2003; Wang and Camp, 2000). However, the color of strawberries became more orange-red after $4 \mathrm{~h}$ (Hue angle increased).

\section{Chemical analysis}

Data in Table 2 give the chemical quality properties of strawberries after heat treatments. The $\mathrm{pH}$ value varied significantly among treatments, with $4 \mathrm{~h}$ heat-treated strawberries showing the highest value. These data conflicted with the findings of previous studies, in which no change of $\mathrm{pH}$ was observed after hot air treatment in strawberries cv. Selva (Vicente et al., 2002; 2003) and Pájaro (Lara et al., 2006). However, our results are more in line with those obtained by using hot water treatment (García et al., 1995; Lara et al., 2006), in which an increase of $\mathrm{pH}$ resulted from increased membrane permeability in heated fruit leading to enzymatic degradation of organic acids liberated from the vacuole. These results can probably explain strawberry changes in softening during treatments. Total soluble solids significantly increased with heat treatment time: samples treated for $4 \mathrm{~h}$ showed the highest SSC content compared to which of other samples. These results are in agreement with García et al. (1995) and Lara et al. (2006) and are probably due to the increased activity of the invertase enzymes in the range of temperatures from 40 to $60^{\circ} \mathrm{C}$ (Ranwala et al.,

Table 1. Effect of air heat treatment time on physical quality properties of strawberry fruit.

\begin{tabular}{|c|c|c|c|c|c|c|}
\hline $\begin{array}{l}\text { Air heat } \\
\text { treatment time } \\
\text { (h at } 45^{\circ} \mathrm{C} \text { ) }\end{array}$ & $\begin{array}{l}\text { Weight } \\
\text { (g) }\end{array}$ & $\begin{array}{l}\text { Firmness } \\
(\mathrm{N})\end{array}$ & $\mathbf{L}^{*} \quad \mathbf{a}^{*}$ & $\begin{array}{l}\text { Extern } \\
b^{*}\end{array}$ & $\begin{array}{l}\text { Ial color } \\
\text { Chroma }\end{array}$ & $\begin{array}{l}\text { Hue } \\
\text { angle }\end{array}$ \\
\hline 0 & $22.70^{\mathrm{a}}$ & $4.42^{\mathrm{a}}$ & $37.41^{\mathrm{a}} 37.44^{\mathrm{a}}$ & $23.35^{\mathrm{a}}$ & $44.17^{\mathrm{a}}$ & $31.95^{\mathrm{a}}$ \\
\hline 2 & $19.30^{\mathrm{b}}$ & $3.27^{\mathrm{b}}$ & $36.81^{a} 33.58^{b}$ & $19.35^{b}$ & $38.81^{\mathrm{b}}$ & $29.95^{b}$ \\
\hline 4 & $17.63^{c}$ & $1.61^{\mathrm{c}}$ & $41.93^{b} 28.03^{c}$ & $18.83^{b}$ & $33.81^{\mathrm{c}}$ & $33.89^{c}$ \\
\hline
\end{tabular}

${ }^{a-c}$ Means for the same parameter in the same column with different letters are significantly differen $(\mathrm{P}<0.05)$.

Table 2. Effect of air heat treatment time on chemical quality properties of strawberry fruit.

\begin{tabular}{cccccc}
$\begin{array}{c}\text { Air heat } \\
\text { treatment time } \\
\left.\text { (h at } 45^{\circ} \mathrm{C}\right)\end{array}$ & $\mathrm{pH}$ & $\begin{array}{c}\text { SSC } \\
(\%)\end{array}$ & $\begin{array}{c}\text { Total } \\
\text { anthocyanins } \\
(\mathrm{mg} \text { PGN/g) }\end{array}$ & $\begin{array}{c}\text { TSP } \\
(\mathrm{mg} \text { GAE/g) }\end{array}$ & TAA \\
0 & $3.48^{\mathrm{a}}$ & $8.97^{\mathrm{a}}$ & $0.21^{\mathrm{a}}$ & $1.75^{\mathrm{a}}$ & $0.61^{\mathrm{a}}$ \\
2 & $3.54^{\mathrm{b}}$ & $10.25^{\mathrm{b}}$ & $0.20^{\mathrm{a}}$ & $1.98^{\mathrm{a}}$ & $0.54^{\mathrm{b}}$ \\
\hline 4 & $3.62^{\mathrm{c}}$ & $11.67^{\mathrm{c}}$ & $0.15^{\mathrm{b}}$ & $2.55^{\mathrm{c}}$ & $0.40^{\mathrm{c}}$ \\
\hline
\end{tabular}

SSC, soluble solids content; TSP, total soluble phenolics; TAA, total ascorbic acid; PGN, pelargonidin-3glucoside; GAE, gallic acid equivalents; a-cmeans for the same parameter in the same column with different letters are significantly different $(\mathrm{P}<0.05)$.

Table 3. Effect of air heat treatment time on DNA quality properties of strawberry fruit.

\begin{tabular}{|c|c|c|c|c|c|c|}
\hline \multirow{2}{*}{$\begin{array}{l}\text { Air heat treatment time } \\
\text { (h at } 45^{\circ} \mathrm{C} \text { ) }\end{array}$} & \multirow{2}{*}{$\begin{array}{l}\text { HMW DNA } \\
\text { presence }^{\circ}\end{array}$} & \multirow{2}{*}{$\begin{array}{l}\text { DNA yield } \\
(\mu \mathrm{g} / \mathrm{g})\end{array}$} & \multicolumn{2}{|c|}{ DNA purity } & \multicolumn{2}{|c|}{ Multiplex PCR $^{\circ}$} \\
\hline & & & $\mathrm{A}_{260} / \mathrm{A}_{280}$ & $\mathbf{A}_{260} / \mathbf{A}_{230}$ & $\operatorname{trn} L-F$ & cad \\
\hline \multicolumn{7}{|l|}{ Achenes } \\
\hline 0 & $30 / 30$ & $145.93^{\mathrm{a}}$ & $2.01^{\mathrm{a}}$ & $1.38^{\mathrm{a}}$ & $30 / 30$ & $30 / 30$ \\
\hline 2 & $30 / 30$ & $107.13^{b}$ & $1.82^{\mathrm{b}}$ & $1.21^{\mathrm{b}}$ & $30 / 30$ & $30 / 30$ \\
\hline 4 & $30 / 30$ & $53.76^{\mathrm{c}}$ & $1.64^{\mathrm{c}}$ & $0.79^{c}$ & $30 / 30$ & $30 / 30$ \\
\hline \multicolumn{7}{|l|}{ Thalamus } \\
\hline 0 & $30 / 30$ & $30.07^{\mathrm{a}}$ & $1.96^{\mathrm{a}}$ & $1.30^{\mathrm{a}}$ & $30 / 30$ & $30 / 30$ \\
\hline 2 & $30 / 30$ & $14.66^{\mathrm{b}}$ & $1.66^{\mathrm{b}}$ & $0.98^{b}$ & $0 / 30$ & $15 / 30$ \\
\hline 4 & $0 / 30$ & - & - & - & - & - \\
\hline
\end{tabular}

${ }^{\circ}$ Numbers shown are positive cases/total cases; ${ }^{a-c}$ means for the same parameter in the same column with different letters are significantly different $(\mathrm{P}<0.05)$. 
1992). No significant differences in anthocyanin content was found in samples heated for 0 and $2 \mathrm{~h}$. Similar results were found heating strawberries for $3 \mathrm{~h}$ at $45^{\circ} \mathrm{C}$ (Vicente et al., 2002; 2003). In contrast, when heated for $4 \mathrm{~h}$, strawberries showed less anthocyanins compared to the other samples. No significant differences in total soluble phenolics was found in samples heated for 0 and $2 \mathrm{~h}$ : these results are supported by those found by Vicente et al. (2003). However, the highest TSP content was exhibited by the samples collected after $4 \mathrm{~h}$ of treatment. The increasing treatment time decreases TAA content, which was lower at $4 \mathrm{~h}$ than 2 and $0 \mathrm{~h}$, respectively. These results are in agreement with the findings of Wang and Camp (2000), who reported that the vitamin $\mathrm{C}$ content could decrease as temperature increased.

\section{DNA analysis}

Table 3 shows the DNA quality properties of strawberries during treatment time. Agarose gel (Figure not shown) analysis showed that HMW bands of DNA extracted from achenes were detected successfully for all treatments. In contrast, when DNA was extracted from thalamus, bands were detected only for those samples that have been sub-

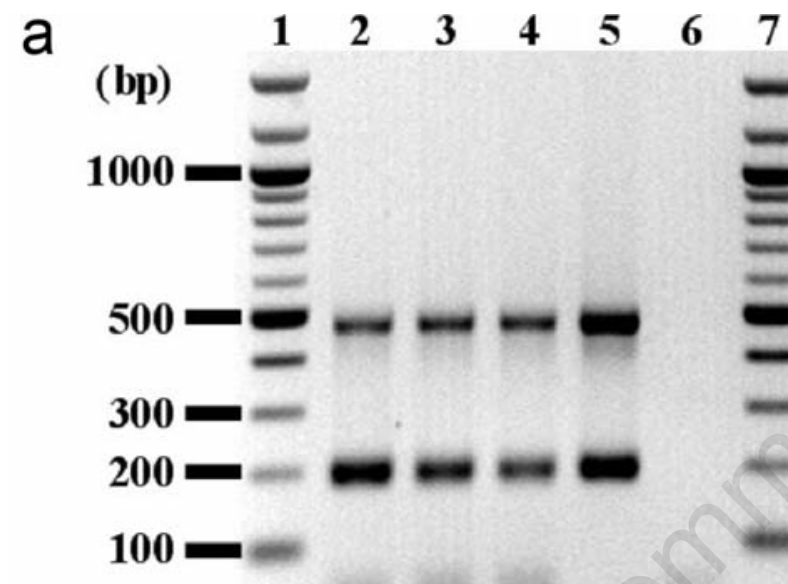

b

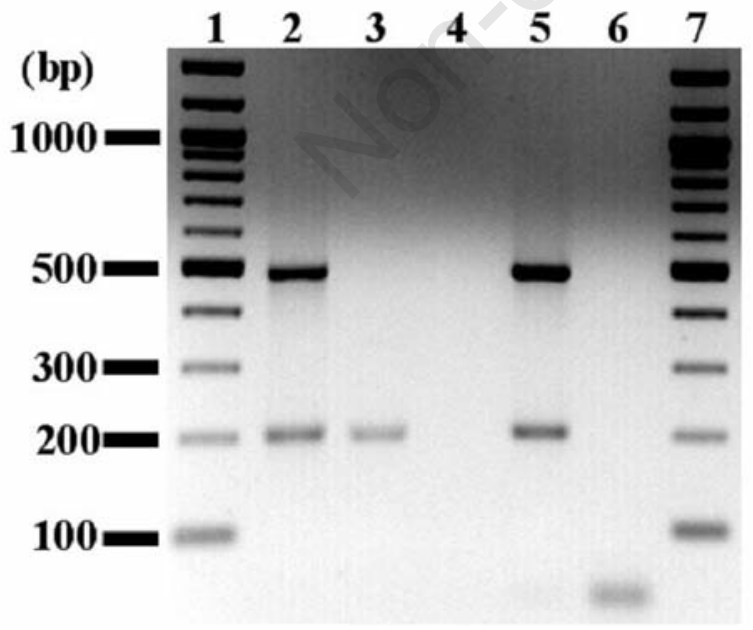

Figure 1. Agarose gel (1.5\%) electrophoresis of Multiplex PCR products generated after amplification of DNA extracted from air heat-treated strawberry fruit. (a) Achenes. (b) Thalamus. Line 1, $7=100 \mathrm{bp}$ marker; line $2=45^{\circ} \mathrm{CxO} \mathrm{h}$; line $3=45^{\circ} \mathrm{C} \times 2 \mathrm{~h}$; line $4=45^{\circ} \mathrm{C} \times 4 \mathrm{~h}$; line 5=PCR positive control; line $6=\mathrm{PCR}$ negative control. jected to 0 and $2 \mathrm{~h}$ of treatment. However, HMW bands became fainter for both tissues as treatment time increased. Besides, the increasing treatment time resulted in more impurities in genomic DNA preparations, such as carbohydrates and phenols, which hindered migration of DNA out of wells and caused non-uniform electrophoretic mobility. It is well known that these cytoplasmic compounds can come into contact with nuclei and other organelles (Loomis, 1974) and do not result in good standards in terms of DNA quality and yield. These results were confirmed by a significant decrease of DNA purity during treatments: $\mathrm{A}_{260} / \mathrm{A}_{280}$ and $\mathrm{A}_{260} / \mathrm{A}_{230}$ absorption ratios decreased from $2.01(0 \mathrm{~h})$ to 1.64 $(4 \mathrm{~h})$, and from $1.38(0 \mathrm{~h})$ to $0.69(4 \mathrm{~h})$, respectively, in achenes. A similar trend was observed in thalamus, with strawberries treated for $0 \mathrm{~h}$ showing the highest absorption ratios (1.96 and 1.30, respectively). These data confirm that heat treatment can increase contamination of the sample by carbohydrates, phenols and other substances which can also interfere in DNA quantification, since they exhibit absorbance at both $230 \mathrm{~nm}$ and at $260 \mathrm{~nm}$. Significant was the effect of heat treatment time on DNA yield in both tissues $(\mathrm{P}=0.000)$, although the damage was lower in achenes than in thalamus. As treatment time increased, the amount of DNA extracted from achenes decreased from $145.93(0 \mathrm{~h})$ to $53.76(4 \mathrm{~h}) \mu \mathrm{g}$ per gram of tissue. The yield of DNA extracted from thalamus was higher when samples were treated for $0 \mathrm{~h}$ than for $2 \mathrm{~h}(30.07$ $\mu \mathrm{g} / \mathrm{g}$ vs. $14.66 \mu \mathrm{g}$, respectively). The DNA yield from $0 \mathrm{~h}$ heat-treated achenes was higher than that (approximately $40 \mu \mathrm{g}$ per gram of tissue) obtained from seeds of other polysaccharide-rich plants, such as Glycine max, Cicer arietinum, Triticum aestivum and Sorghum bicolour (Sharma et al., 2002), whereas the amount extracted from 0 h heattreated thalamus was comparable to that (4.7 $\mu \mathrm{g}$ per g) obtained from fresh pear (Yamamoto et al., 2006). Different results were described from strawberry leaves by Mercado et al. (1999), who obtained 50-120 $\mu \mathrm{g} / \mathrm{g}$, and by Hanhineva and Kärenlampi (2007), who obtained $30-50 \mu \mathrm{g} / \mathrm{g}$. The different responses in terms of quality and yield of DNA to heat treatments are probably due to the botanical difference between achenes (true fruit) and thalamus (receptacle), and to their difference in terms of total phenolic, flavonoid and anthocyanin content (Cheel et al., 2007). As shown in Table 3, the DNAs extracted from achenes resulted suitable for multiplex PCR. For all treatments, amplification of the trnL-F and cad target sequences resulted in two bands at the expected molecular size of 500 and $209 \mathrm{bp}$, respectively. However, bands became fainter as treatment time increased (Figure 1a,b), thus confirming that the yield and/or the quality of the extracted DNAs was affected by heat treatments. Different results were observed for thalamus: all of the templates obtained for samples heated for $0 \mathrm{~h}$ produced two specific amplification bands (100\% of the successful amplifications for both genes). In contrast, when strawberries were heated for $2 \mathrm{~h}$, amplification was observed for the cad gene (100\% of the successful amplifications) but not for the trnL-F gene (Table 3), revealing that long DNA strands were not intact. A similar result was reported by Yamamoto et al. (2006) using DNAs from canned fruits and fruit juice in pear for trnL-F amplification. No products could be obtained from samples heated for $4 \mathrm{~h}$, confirming that the size and the quality of their DNAs were not satisfactory for amplification.

\section{Conclusions}

In the present study, the effects of heating $\left(45^{\circ} \mathrm{C}\right)$ Candonga strawberry fruits for different times $(0,2$ and $4 \mathrm{~h})$ were investigated. When air heat treatment time increased, strawberry weight decreased significantly, as well as fruit firmness. The latter result is in contrast with the findings from previous studies in Selva strawberries (Civello et al., 1997; Vicente et al., 2002), thus confirming contradictory results related to the same cultivar and among cultivars (Lara et al., 2006; 
Yoshikawa et al., 1992; Vicente et al., 2003, 2005). Heat-treated fruits reduced their redness ( $a^{*}$ value) and their pigment intensity (Chroma value) with time, whereas lightness ( $L^{*}$ value) loss was significant only after 4 . Hue angle decreased when fruit were treated for $2 \mathrm{~h}$, and increased after $4 \mathrm{~h}$. As exposure of fruit increased, positive effects were observed on solid soluble content and total soluble phenolics, as response of the invertase and PAL enzymes, respectively. However, negative effects were observed in other chemical quality properties, such as $\mathrm{pH}$, total anthocyanins and vitamin $\mathrm{C}$ content. Air heat treatment time had a negative effect on quality and yield of genomic HMW DNAs extracted from strawberry fruits. Electrophoresis, spectrophotometry and multiplex PCR analysis showed a progressive reduction of DNA quality during treatments. However, observed differences were much more negative in thalamus than in achenes, since strawberry identification was always obtained using DNAs extracted from the latter matrix. Therefore, as well as providing a method of product authentication, DNA quality parameters used in this study would also offer the possibility of designing, checking and improving postharvest treatments (Lurie, 1998), which could maintain fruit quality throughout the production chain. However, further studies on the effects of other heat treatments (i.e. hot water, etc.) on quality properties of Candonga strawberry fruits, even in relation to storage or shelf life periods, are needed to better understand their different behaviour respecting previous results on other cultivars.

\section{References}

Agarwal A., Makker A., Goal S., 2002. Application of the PCR technique for a rapid, specific and sensitive detection of Salmonella spp. in foods. Mol. Cell Probes 16:243-250.

Arslan A., Ilhak 0.I., Calicioglu M., 2006. Effect of method of cooking on identification of heat processed beef using polymerase chain reaction (PCR) technique. Meat Sci. 72:326-330.

Charalambous G. 1984. Analysis of food and beverages. Academic Press, Orlando, FL, USA.

Cheel J., Theoduloz C., Rodríguez J.A., Caligari P.D.S., SchmedaHirschmann G., 2007. Free radical scavenging activity and phenolic content in achenes and thalamus from Fragaria chiloensis ssp. chiloensis, F. vesca and F. x ananassa cv. Chandler. Food Chem. 102:36-44.

Civello P.M., Martínez G.A., Chaves A.R., Añón M.C., 1997. Heat treatments delay ripening and postharvest decay of strawberry fruit. J. Agr. Food Chem. 45:4589-4594.

Cordenunsi B.R., Nascimento J.R.O., Genovese M.I., Lajolo F.M., 2002. Influence of cultivar on quality parameters and chemical composition of strawberry fruits grown in Brazil. J. Agr. Food Chem. 50:2581-2586.

Couey H.M., Follstad M.N., 1966. Heat pasteurization for control of postharvest decay in fresh strawberries. Phytopathology 56:13451347.

García J.M., Aguilera C., Albi M.A., 1995. Postharvest heat treatment on Spanish strawberry (Fragaria $\mathrm{x}$ ananassa cv. Tudla). J. Agr. Food Chem. 43:1489-1492.

Halliwell, B., 1994. Free radicals, antioxidants and human disease: Curiosity, cause or consequence. Lancet 344:721-724.

Hanhineva K.J., Kärenlampi S.0. 2007. Production of transgenic strawberries by temporary immersion bioreactor system and verification by TAIL-PCR. BMC Biotechnol. 7:11.

Hannum S.M., 2004. Potential impact of strawberries on human health. Crit. Rev. Food Sci. Nutr. 44:1-17.

Heinonen I.M., Meyer A.S., Frankel E.N., 1998. Antioxidant activity of berry phenolics on human low-density lipoprotein and liposome oxidation. J. Agr. Food Chem. 46:4107-4112.

Ho C.T., Shahidi F., 2005. Phenolic Compounds in Foods and Natural Health Products. American Chemical Society, Washington, DC, USA.

Hubner P., Waiblinger H.U., Pietsch K., Brodmann P. 2001. Validation of PCR methods for quantitation of genetically modified plants in food. J. AOAC Int. 84:1855-1864.

Ketsa S., Chidtragool S., Klein J.D., Lurie S., 1998. Effect of heat treatment on changes in softening pectic substances and activities of polygalacturonase, pectinesterase and beta-galactosidase of ripening mango. J. Plant Physiol. 153:457-461.

Knight A.I., 1998. Method for detecting a particular plant species in a product. Patent WO 1998/014607.

Lara I., García P., Vendrell M., 2006. Post-harvest heat treatments modify cell wall composition of strawberry (Fragaria $\mathrm{x}$ ananassa Duch.) fruit. Sci. Hortic.-Amsterdam 109:48-53.

Loomis M.D., 1974. Overcoming problems of phenolics in the isolation of plant enzymes and organelles. Meth. Enzymol. 31:528-545.

Lurie S., 1998. Postharvest heat treatments. Postharvest Biol. Tec. 14:257-269.

McGuire R.G., 1992. Reporting of objective color measurements. HortScience 27:1254-1255.

Mercado J.A., EL Mansouri I., Jimenez-Bermudez S., Pliego-Alfaro F., Quesada M.A., 1999. A convenient protocol for extraction and purification of DNA from Fragaria. In Vitro Cell. Dev.-Pl. 35:152153.

Meyer R., Hofelein C., Luthy J., Candrian U., 1995. Polymerase Chain Reaction-Restriction Fragment Length Polymorphism Analysis: A simple method for species identification in food. J. AOAC Int. 78:1542-1551.

Miller D., 1998. Food chemistry: A laboratory manual. John Wiley and Sons. New York, NY, USA.

Peano C., Samson M.C., Palmieri L., Gulli M., Marmiroli N., 2004. Qualitative and quantitative evaluation of the genomic DNA extracted from GMO and non-GMO foodstuffs with four different extraction methods. J. Agr. Food Chem. 52:6962-6968.

Piknova L., Krahulcova J., Kuchta T., 2002. Detection of the cow's milk component in ewe's and goat's cheese using polymerase chain reaction. Bull. Food Res. 41:163-167.

Ranwala A.P., Suematsu C., Masuda H., 1992. Soluble and wall-bound invertases in strawberry fruit. Plant Sci. 84:59-64.

Rice-Evans C.A., Miller N.J., 1996. Antioxidant activities of flavonoids as bioactive components of food. Biochem. Soc. T. 24:790-795.

Sanjuan A., Comesana A.S., 2002. Molecular identification of nine commercial flatfish species by polymerase chain reaction-restriction fragment length polymorphism analysis of a segment of the cytochrome b region. J. Food Protect. 65:1016-1023.

Shapiro S.S., Wilk M., 1965. An analysis of variance test for normality. Biometrika 52:591-611.

Sharma A.D., Gill P.K., Singh P., 2002. DNA Isolation From Dry and Fresh Samples of Polysaccharide-Rich Plants. Plant Mol. Biol. Rep. 20:415a-415f.

Singleton V.L., Rossi J.A., 1965. Colorimetry of total phenolics with phosphomolybdic-phosphotungstic acid reagents. Am. J. Enol. Viticult. 16:144-158.

Tilley M. 2004. PCR amplification of wheat sequences from DNA extracted during milling and baking. Cereal Chem. 8:44-47.

Vicente A.R., Costa M.L., Martínez G.A., Chaves A.R., Civello P.M., 2005. Effect of heat treatments on cell wall degradation and softening in strawberry fruit. Postharvest Biol. Tec. 38:213-222.

Vicente A.R., Martínez G.A., Chaves A.R., Civello P.M., 2003. Influence of self-produced $\mathrm{CO} 2$ on postharvest life of heat-treated strawberries. Postharvest Biol. Tec. 27:265-275.

Vicente A.R., Martínez G.A., Civello P.M., Chaves A.R., 2002. Quality of 
heat-treated strawberry fruit during refrigerated storage. Postharvest Biol. Tec. 25:59-71.

Wang C.Y., 1998. Heat treatment affects postharvest quality of kale and collard but not of brussels sprouts. HortScience 33:881-883.

Wang H., Cao G., Prior R.L. ,1996. Total antioxidant capacity of fruits. J. Agr. Food Chem. 44:701-705.

Wang S.Y., Camp M.J. 2000. Temperatures after bloom affect plant growth and fruit quality of strawberry. Sci. Hortic.-Amsterdam 85:183-199.
Watson N., 2010. Candonga strawberry has 50\% market share in Southern Italy. Available from: http:/www.freshplaza.com/news_ detail.asp?id=58202

Woodward J.R., 1972. Physical and chemical changes in developing strawberry fruits. J. Sci. Food Agr. 23:465-473.

Yamamoto T., Kimura T., Hayashi T., Ban Y., 2006. DNA profiling of fresh and processed fruits in pear. Breeding Sci. 56:165-171.

Yoshikawa F.T., Mitchell F.G., Mayer G., 1992. Moist heat treatments of strawberries are studies. Calif. Agr. 46:26-28. 